\title{
The influence of cultural practices on the HIV and AIDS pandemic in Zambia
}

\begin{abstract}
Authors:
Nolipher Moyo ${ }^{1}$

Julian C. Müller ${ }^{1}$

Affiliations:

${ }^{1}$ Department Practical

Theology, University of

Pretoria, South Africa

Note:

Nolipher J. Moyo has done the primary research as

part of her PhD degree in

Pastoral Family Therapy

under supervision of

Prof. Julian C. Müller of

the Department Practical

Theology, University of

Pretoria, South Africa.

Correspondence to:

Julian Müller

email:

julian.muller@up.ac.za

Postal address:

PO Box 626, Wapadrand

Petoria 0002, South Africa

Dates:

Received: 24 Nov. 2010

Accepted: 08 July 2010

Published: 09 May 2011

How to cite this article:

Moyo, N. \& Müller, J.C.,

2011, 'The influence of

cultural practices on the

HIV and AIDS pandemic

in Zambia' HTS Teologiese

Studies/Theological Studies

67(3), Art. \#770, 5 pages.

DOI: $10.4102 /$ hts.v67i3.770
\end{abstract}

(C) 2011. The Authors. Licensee: OpenJournals Publishing. This work is licensed under the Creative Commons Attribution License.
Culture plays a significant role in people's lives in Zambia and in Africa as a whole. Consequently, there is a need to take Zambian or African culture seriously in order to look at the salient elements of cultural practices in rites of passage that influence the spread of HIV and AIDS. This article analyses four rites of passage associated with birth, puberty, marriage and death. There are numerous rites of passage in Zambian culture. Some of these rites help to curb the spread of HIV and AIDS, whilst others exacerbate the spread of the virus. Using the Reformed Church in Zambia Bible Study Method of Subgroups, discussions were held that allowed victims of cultural practices to tell their stories using the narrative model. This article sought to shed light on cultural practices that exacerbate HIV and AIDS and more importantly, provide culturally sensitive alternatives to these harmful practices.

\section{Introduction}

In a report to the BBC Radio on 01 December 2004, Kofi Annan, the former United Nations secretary General, reported that sub-Saharan Africa has the highest rate of HIV and AIDS infections and that women are the most affected by this pandemic. There are many factors that have lead to the high rate of HIV and AIDS in sub-Saharan Africa. One is inclined to ask whether Africans are more promiscuous than their European or American counterparts. There is no evidence to support this idea. After living in the United States of America (USA) and travelling in Europe, I feel that the opposite may be true. This leads to the question of what other factors may help to explain the spread of HIV and AIDS in sub-Saharan Africa. There is little to no research on the role that rites of passage and other cultural practices have had on the spread of HIV and AIDS in sub-Saharan Africa. Some cultural practices have helped to curb the disease, whilst others exacerbate the spread of HIV and AIDS in Africa.

There is an urgent need to establish the causes of the high rate of the HIV infection in Africa, so that appropriate strategies can be put in place to combat this pandemic. A need also exists to understand whether the cultural practices of Zambians have an influence on the spread of HIV and AIDS. My experience has influenced me to take a serious look at the salient cultural practices that put women at serious risk of contracting HIV and AIDS. The good cultural values, which can help in the fight against HIV and AIDS, are dying out whilst the bad ones, that promote the spread of the disease, continue to exist. Society should see the need to promote good cultural values and discourage bad ones. There have been many women infected with HIV in Zambia and Africa as a whole. The United Nations Children's Fund (UNICEF) (1994:4) report says that women are more vulnerable to AIDS than men, for a number of reasons such as the collapse of support systems and therefore there is a need to intensify our efforts to promote effective joint involvement into finding the solution to this problem.

This article will examine the influence of cultural practices on the HIV and AIDS pandemic in Zambia. It will provide an understanding of women's untold stories about salient cultural practices of Zambian rites of passage that promote or hinder the spread of HIV and AIDS. As a researcher, I wanted to be a part of the discussion on the influence of cultural practices during rites of passage on the spread of HIV and AIDS amongst the Zambian people, especially amongst women and female children. The rites of passage in question are those associated with birth, puberty, marriage and death.

\section{Methodology}

This research was based on a number of pertinent methods, which include literature reviews, interviews, conversation and field studies. The main source of data was field trips and the conducting of qualitative interviews. 
The women are the ones who are involved in rites of passage. They follow the demands of their cultural beliefs. They also believe that if they do not carry out these rites of passage something bad will happen to them.

As a result, my primary partners in conducting this research were the ordinary women of Zambia; they are the ones who have the stories to tell. They are the caregivers in the community. Three focus groups, comprised randomly selected men and women, were interviewed (the men and women were interviewed separately). The participants were randomly selected by their congregation leaders, who were pastors, laymen, laywomen and the youth, who met at Justo Mwale Theological College Booth Center on 25 and 27 May 2005. The participants first explored and described Zambian cultural practices that take place during rites of passage. As the participants felt free to describe and explain the cultural practices in their sub-focus-group discussions, they prepared the ground for many women and men to share their personal stories with me. Some shared the stories of their relatives who had been victims of some cultural practices. The focus group discussions brought release to many women, by allowing them the opportunity to share what they had kept within themselves for some time. These were women from different backgrounds who shared their stories, narrating how they became victims of some of the cultural practices, discussed later in this article. Some of the women were HIV positive; some had gone for voluntary counselling and testing (VCT), but emotionally they were not strong enough to deal with their results.

We travelled together through stories. Through stories of experiences, we were able to interpret the problems facing the women of the society, and discuss possible alternatives to these problems. Through telling the stories the social realities were found. 'A story communicates a moral, a broad message, or a set of core beliefs' (Rubin \& Rubin 1995:25). Most interviewers value stories, because most of the time they contain issues that the interviewee feels too awkward to share directly, but will tell in a story.

Gergen (1985:266) describes social construction discourse as the processes by which people come to describe, explain or account for the world in which they live. Here, knowledge is seen as something socially constructed into the language that makes people communicate. Gergen (1985), further states that knowledge is not something people possess somewhere in their heads, but rather something that they do together. This is why we must explore the phenomenon of cultural practices to interpret the stories into the language that a person can understand. Freedman and Comb (1996:57) pointed out that deconstruction can help us unmask the 'so called truth'. This hides biases and prejudices behind the disembodied way of speaking, giving an air of legitimacy to restrictive and subjugating dominant stories. That is why practical theology has a part to play, to make room for people to encounter God, and live in fellowship with God and others.

HIV and AIDS have also, to a very large extent, effected the Church. 'Ministers are burying more people than they are baptising!' as one Zambian theologian, Dr A. Kasambala
(2003:1), once said. This may be an alarming statement, but it is very much true in our present scenario. HIV and AIDS have brought a new dimension to the theology of suffering, in which pastoral care and counselling is very much involved.

The results of this study will be shared with members of the Reformed Church in Zambia and some other member churches under the Christian council of Zambia. Presently, the church in Zambia is encouraging people to find means and ways to discourage evil ways and promote biblical morals, which will make the world a better place to live in. The results will also be shared in some interdenomination churches, even the Pentecostal churches through the Pastor's Wives Fellowship, anti-AIDS groups, women's lobby groups, NGOs and other social work groups.

\section{Practical Theology}

Van Niekerk, quoting Heyns (1990:6), expresses that practical theology is 'that part of theology that concerns itself with this event - the encounter between God and humanity - and particularly with the role of human beings in this encounter'. Practical theology seeks to help humans to encounter God and live to in fellowship with God and other people. It is concerned with those religious actions that communicate with others so as to make room for God in this world. Living amongst people in society, practical theology becomes a way of life amongst the people you live with. Therefore, in order for this study to succeed, I needed to join the people of Zambia in their daily challenges of life, such as birth in the family, initiation, weddings, funerals and other ceremonies.

Zambia is believed to be about $80 \%$ Christian and as a result, in order to address a problem like HIV and AIDS, the church and religion will have to be part of the societal dialogue. The alternative practices proposed in this article also include Christian alternatives.

\section{Cultural practices in line with birth}

Children are of special value to both men and women in African societies. It has been pointed out that the respect and status that motherhood confers on a woman is greater than that conferred by marriage (Dolphyne 1991:30). In many cultures in Africa, people marry because they want to have children. If a woman does not give birth she can be divorced or another wife taken to produce children for the husband. According to Drews (1995:33), 'In many Zambian tribes no one talks about pregnancy and birth'. This is because they fear that the pregnant woman may be bewitched at the time of delivery. The delivery day is also kept secret.

Motherhood is defined as the fullest acceptability in the world of female adulthood. Children give status to a woman. The woman without a child in African society is treated as a young person. If the problem lies with the man, if he is infertile for example, he will be advised to drink some herbs to increase the power of his manhood. If he is still unable to conceive a child with his wife, then the family will arrange 
someone to sleep with his wife until she conceives. This is kept a closely guarded secret between the husband, the hired man, the wife and the family member who made the arrangement (Moyo 2001:100).

The situation is grave for girls, particularly when they are orphaned, as is clear from the personal experience of Tibale. Tibale of the Kamanga compound said that her relatives have nicknamed her 'Eve' meaning she is evil and deserves punishment for her status. She added that, she is being labelled a killer by her own relatives:

'They called me Eve from the time I got sick and they say I have brought problems in a peaceful garden," she said. "I am a decent girl from a decent family, but because of following the advice of some elderly women, who look innocent now, I am blamed to have brought AIDS into my family after allowing a man to sleep with me so that I can conceive. I was unable to conceive with my husband and so the elderly women in my family made arrangements for me to sleep with another man to conceive a child. The world is unfair. I don't understand it. May God help me. I am now the victim of fate. I am now HIV positive and pregnant.'

\section{The possibility of HIV transmission}

The girl did not know the HIV status of the man she had sex with, nor did she know her husband's status. If she is HIV positive, then both the man and the husband can be infected. If this man is HIV positive, he can infect her, the coming baby and the husband. If her husband was HIV positive, then he can infect his wife and the coming baby and also the man she had sex with and his future partners.

\section{Possible alternatives}

They should see a doctor who can examine them and give them advice. Those who decide to follow this practice should ensure that both parties have been tested and are not infected by HIV. If the man asked to father the child, tests positive for HIV, then another man should be found. Alternatively, they could adopt children using legal methods or using a traditional way, where the couple asks one of the relatives who has many children if they may take care of one. If the parents of the child agree, then that couple should invite this particular child to live with them. This child will be treated well, with many favours, so that he or she forgets about their real parents.

\section{Cultural practices in line with puberty}

Puberty is the stage at which an individual is described as having reached adulthood. It means an individual is then regarded as a responsible member of the clan and of the whole society (Breugel 2001:191). Puberty is a very important right of passage for girls in many African cultures. The rite is associated with the beginning of menstruation, which is believed to be a sign of growing up. Girls are taught how to keep themselves clean during the menstrual period, but above all, they are taught how to use the newly acquired powers of life. A girl is told to be careful in her conduct and relationships with others (Breugel 2001:186). The stage of puberty is an important entry point for reproductive health messages. The traditional initiators form an important group in the society through which reproductive health messages can be passed on to young people. The whole initiation period sets a stage for reaching out to adolescents. 'Pre-marital sex is forbidden among the Tumbukas and the Ngonis. From the time of a girl's first menstruation her life becomes confined' (Oke 1991:95).

Amongst the Chewa people, the initiation ceremony ends with a ritual at the end of puberty (Kutha Cinamwali). Breugel mentions that on the last day the girl's head is shaven (Moyo 2001). If the girl is married, on the last night of the initiation, her husband comes to the house. The namkungwi [instructor] instructs her husband to have relations with her to show that they were well instructed during the initiation. By doing that her husband imparts his strength to her and she becomes strong again. If the girl is not yet married, or if her husband is away, another young man is chosen to act as her husband on the last night of her seclusion. The girl's parents bring a rooster that is eaten by this young man, so as to give him strength. This young man is called a fisi [puberty hyena], because he comes secretly and he is given money by the girl's parents.

Kutha Cinamwali appears to be a rite of passage that is likely to lead to the spread of HIV and AIDS amongst the Chewa people. If the fisi [puberty hyena] is infected with HIV, then the girl can contract the virus too and may infect the man whom she is going to marry as well! This is in contrast with Christianity, as Christians are told to keep their bodies pure because they are the temple of God. Sex before marriage is neither acceptable by Christian morals nor those of other African cultures. Ngulube indicates that patriarchal societies, for example the Ngoni, emphasise the importance of virginity before a woman is married. In such tribes, elderly women often conduct physical examinations of girls to ensure that they are virgins before they enter into marriage. This is in sharp contrast with matrilineal societies, for example the Chewa, who strongly believe that a girl would die if she did not copulate at puberty (Ngulube 1989:98).

\section{The possibility of HIV transmission}

If the fisi was HIV positive, the possibility of the girl being infected with the virus is there. Or, if she was infected, the fisi could be infected too. It seems the concern of contracting AIDS was there, but they had intercourse without the protection of a condom.

\section{Alternative method}

As an alternative method, a condom or some medicine that does the same work as the sexual act can be used. If they are Christians, the pastor can pray for the girl to be in God's protection, by using anointing oil or holy water if they want to see tangible objects. In many rural areas of Zambia, most of the girls do not go to school and as a result are married early. They mostly get married to elderly men who sometimes 
take them as second or third wives. The prime minister of Mozambique, Pascoal Mocumbi, wrote in the New York Times (2004:6): 'The United Nations estimates that thirty-seven percent of the sixteen year-olds in my country will die of Aids before they are thirty'. He (2004) further notes:

In Mozambique, the overall rate of HIV infection among girls and young women is 15 percent, which is twice that of boys of their age, not because the girls are promiscuous, but because nearly three out of five are married by the age of eighteen, 40 percent of them to much older, sexually experienced men who may expose their wives to HIV and sexually transmitted diseases.

(New York Times 2004:6)

Early marriages became a social-pride of the family. Sometimes girls were taken into their marital homes before they even reached puberty. But nowadays, when the girl reaches puberty, at 12-14 years of age, she is expected to get married immediately, although still a child. The belief that results in these early marriages is that if women do not marry early, they wash away children during their menses (as said by 72 years old Nukwase). As a result, the ancestral spirits are unhappy and when the woman marries later she will not have children. Following, is a story of a young girl who is HIV positive because of an early marriage.

\section{Cultural practices in line with marriage}

Marriage is when a man and a woman, who are attached to each other, love each other and live together, sharing the gift of companionship, sex and reproduction until death parts them.

(Dolphyne 1991:1)

In Zambian traditional society, a man marries a woman; it is a taboo for a woman to do so in either traditional or modern society in Zambia.

In most sub-Saharan African countries, children are the most important part of marriage. A marriage without children is often considered incomplete or lacking, and failure to produce a child is considered to be shameful to both the husband and the wife.

If there is no news of conceiving after a certain period of time, the relatives of the man will sometimes ask him to have an affair with another girl, to see if she conceives. If she does, the blame will be on the wife. Sometimes a woman will be advised to have a secret affair so that when she conceives she can tell her husband that she is pregnant and the husband will think it is his. The only people who know the secret is the woman and her advisors. The boyfriend is not told that a child has been conceived and cannot know, because she is someone else's wife (Ngulube 1989:86).

Amongst the Ngoni and Tumbuka people, if a man cannot have an offspring, special arrangements are made in secret for another man, a fisi [marriage hyena] to produce children on his behalf. Sometimes the hired co-husband pays something to the sterile man (Ngulube 1989:96), but in some villages, the hired man is paid for the work well done by the lady's husband. This payment is necessary to ensure that the arrangement is kept a secret. Such hired men are usually good and trusted friends of the sterile husbands. According to Radcliffe-Brown and Ford (1970:217), 'a husband's brother may produce children by the wife if the husband is important and may inherit her if she becomes a widow'. This society feels it should find a solution to every problem.

This type of advice is not biblical, given the fact that God did not create the institute of marriage for the sole purpose of having children only, but for the partners to enjoy and care for each other. It is a risk to have extra-marital affairs in this day and age, which could infect the wife or husband with HIV and AIDS. As Christians, we believe that God is the one who gives children as a blessing in marriage. God blesses people differently and the society needs to understand this. Failure to acknowledge this could be viewed as the reason why the reproductive age group in Zambia is dying. God opened the womb of Sarah in her old age. Elizabeth, who was considered barren, was able to have a powerful child. Hannah was the laughing stock of the women in her tribe because she was barren. God heard the cry of these women and opened their wombs. Therefore, if one wants an offspring, one should pray to God, and he will give children if it is his will.

\section{Cultural practice in relation to death}

In many African cultures, death is not accepted as a natural occurrence. 'In most cases death is attributed to evil deeds of fellow men' (Breugel 2001:97). Sickness brings fear of death. When a person becomes gravely ill, all the relatives have to be warned. When they enter their agony, a man will hold the hand of a man and a woman the hand of a woman. The one who supports the dying person will close his or her eyes and mouth each time they are opened, and others will keep the arms and legs straight. They want to make sure that he or she dies with dignity, because death is like sleeping (Bruegel 1991:97).

In most cities, when a person is very sick, they are rushed to the hospital, where they will find help. If the person is very sick and dying, one or two of the person's relatives will be asked not to leave the bed until he or she dies, in order to comfort and support them. Death is something mysterious and frightening and people want to face it together. They are afraid of death itself, afraid of the dead man or woman's spirit, who is believed to enter into a pre-death state before dying. All relatives who will be attending the funeral will refrain from having sexual relations until their loved one has been buried. Those who fail to follow this tradition are said to interfere with the proper ritual of sending off the spirits, which may cause some calamities to fall upon them.

\section{Sexual cleansing}

This ritual is done to remove the spirit of the dead so that the living spouse can start living a normal life again. Emily Wax (2003) provides the following account of sexual cleaning in Gangre Kenya that illustrates the problems associated with this practice:

His breath fumes with the local alcoholic brew. Greasy food droppings hang off his moustache and stain his oily pants and torn shirt. He's always the first one in line for the village feast, 
tucking into buffet carefully prepared by the women of the village like he's diving into the ocean, with no restraint. He is too skinny and the women point out his terrible taste in clothes. But for all of his undesirable traits, Akacha has a surprisingly desirable job: he is paid to have sexual relations with the widows and unmarried women of this village.

He's known as 'the cleanser', one of hundreds of thousands of men in rural villages across Africa who sleep with women after their husbands die, to dispel what villagers believe are evil spirits. As tradition holds, they must sleep with the cleanser to be allowed to attend their husbands' funerals or be inherited by their husbands' brother or relative. Unmarried women who lose a parent or child must sleep with the ritual cleanser.

(Wax 2003:6)

\section{The possibility of HIV transmission}

This custom of sexual cleansing has led to the deaths of 19.6 million people in sub-Saharan Africa. It has become more than just a painful ritual and cleansers are now spreading HIV at explosive rates in villages such as Gangre, where one in every three people is infected.

\section{Alternative methods}

\section{Sliding over}

The Soli people call it 'kwikala pa maulu'. The Tonga calls it 'kusalazya'. The Bemba calls it 'ukuwamya'. In this ritual, the widow or widower sits with his or her legs outstretched. Formerly, women would tuck in a bit of their attire. Then a brother-in-law, sister-in-law, niece or nephew of the deceased would sit down in the lap of the widow or widower. He or she would slide down the bereaved to the feet and go away without looking back. The widow or widower is then loosely tied with a wrist band, a string, a string of white beads or a string of white cotton. As the person moves away, it falls off on its own. This marks the end of the ritual.

\section{Skipping over}

Another way of cleansing widows or widowers is called 'skipping over' or 'sitting on an animal'. This is usually a cow for a man and a bull for a woman. The animal is brought into the threshold of a house very early in the morning and made to lie down with its legs tied. The widow or widower skips over it or sits on it for a short while and then they are taken away from it to release the dead person's spirit. This is done by the Tonga people and called ' $k u c u t a$ '.

\section{Anointing method}

The most common form of cleansing, practiced by many tribes, is the anointing method performed by the Chikunda, Bemba, Chewa, Tonga, Tumbuka, Lunda and Kaonde. The widow or widower is anointed with castor oil or corn meal wrapped in the castor oil leaf and rubbed it on the forehead or chest of the one to be cleansed. The Bemba calls it ' $u k u k u b a$ ubunga'.

\section{Prayer}

In the case of Christians, the pastor prays for them and it is believed that nothing happens to the widow or widower if they believe in God. Some of these other ways are regarded as not biblical and unethical. It is a pity that many people still believe that if they do not go through ritual cleansing they will be haunted by the spirit of the dead person or go mad.

\section{Conclusion}

With one of the highest rates of HIV and AIDS in the world, Zambia and sub-Saharan Africa as a whole needs to examine the various cultural practices that hinder or exacerbate the spread of the disease. There are numerous rites of passage associated with birth, puberty, marriage and death that women go through, which often exposes them to HIV and AIDS. However, there are alternatives to some of these rites that may help to protect women. These include testing the fisi before allowing him to have intercourse with young women who have reached puberty, adoption for couples who cannot conceive their own children and sliding over, skipping over, anointing and prayer in place of sexual cleansing. Such practices could help to curb the spread of HIV and AIDS whilst respecting different tribe's traditions.

Practical theology should approach the issue of cultural practices seriously by empowering women and teaching young girls how they can resist those traditions that may harm them, through the church and institutions like the ministry of education. Men should also learn to be gender sensitive and let the love of God be the standard of life in order to achieve equality. The ways and means should be provided to counsel the victims of the cultural practices that contribute to the spread of HIV and AIDS, and both men and women taught through sub-group Bible studies, so that the community can have an open dialogue on those practices that are harmful and those that are not.

\section{References}

Bruegel, J.W.M., 2001, Chewa traditional religion, CLAIM, Blantyre.

Dolphyne, F.A., 1991, The emancipation of women: An African perspective, Ghana Universities Press, Accra.

Drews, A., 1995, Words and silence: Communication about pregnancy and birth among the Kunda of Zambia, Geborente Braunschweig, Amsterdam.

Freedman, J. \& Combs, G., 1996, Narrative therapy: The social construction of preferred realities, Norton, New York.

Gergen, K., 1985, 'The social construction movement. Modern Psychology', American Psychology, 40, 266-275. doi: 10.1037/0003-066X.40.3.266

Kasambala, A., 2003, HIV/AIDS Awareness Seminar: Breaking the silence, Stellenbosce, NetAct, Lusaka.

Mocumbi, P., 2004, 'Early marriages to elderly men', the New York Times, n.d., p. 6.

Moyo, P.H., 2001, 'The Bible and African culture as source in African Christian ethical decision making', DD thesis, Department of Dogmatics and Christian Ethics, University of Pretoria.

Ngulube, N.M.J., 1989, Some aspects of growing up in Zambia, Nalinga Constance/So consult A/S Limited, Lusaka.

Oke, E.A., 1991, An introduction to social anthropology, MacMillan, Hong Kong.

Radcliffe-Brown, A.R. \& Forde, D., 1950, African systems of kinship and marriage, Oxford University Press, London.

Rubin, H.J. \& Rubin, I.S., 1995, Qualitative Interviewing: The art of hearing data, Sage Publications, Thousand Oaks.

United Nations Children's Fund (UNICEF), 1994, 'Children and Women vulnerability to AIDS', Cambridge University Press, New York.

Van Niekerk, A., 2001, 'Moral and Social Complexities of AIDS', Africa Journal of Philosophy 22(2), 143-162.

Wax, E., 2003, 'Women blame cleansing custom for spreading of HIV', The Star, 20 August, p. 6. 